\title{
PREVALENSI CACING HATI SAPI PERAH PADA PETERNAKAN RAKYAT DI PROVINSI LAMPUNG
}

\author{
Prevalence of Liver Worms of Dairy Cattle Livestock in Lampung Province
}

\author{
Siswanto, Madi Hartono, Purnama Edy Santosa, Sri Suharyati, Hindun Larasati, dan \\ Muhammad Mirandy Pratama Sirat
}

Department of Animal Husbandry, Faculty of Agriculture, Lampung University

Jl. Soemantri Brojonegoro No. 1, Gedong Meneng, Rajabasa, Bandar Lampung 35145

Email : dwicipta_mandiri@yahoo.co.id

\begin{abstract}
The study was conducted on dairy cattle livestock at Lampung Province in July - August 2012, aiming to determine the prevalence of liver worms. Disease in livestock caused by liver worm infections are called Fasciolosis. Fasciolosis is an important parasitic disease because it can cause high economic losses. The research method was the census method. Data retrieval were 125 dairy cattle faecal samples from people's dairy farms in Lampung Province. The datas obtained were analyzed descriptively. Examination of faecal samples was carried out at the Lampung Veterinary Center using the Sedimentation Test. The results showed the prevalence of liver worms in dairy cattle in Lampung Province was 12.00\%, 15 dairy cattle those were positively infested by liver worms. The highest dairy cattle prevalence in West Lampung Regency at 33.33\%, while the lowest prevalence is in dairy cattle in Bandar Lampung City and Tanggamus Regency at $0 \%$.
\end{abstract}

Keywords: Dairy Cattle Livestock, Lampung Province, Liver Worms, Prevalence, Sedimentation Test

\section{PENDAHULUAN}

Sapi perah merupakan salah satu ternak yang memiliki produk akhir berupa susu. Kesadaran masyarakat akan pentingnya kebutuhan protein hewani menjadikan susu sebagai salah satu produk hasil peternakan yang makin diminati. Menurut Kementerian Pertanian RI (2015), jumlah populasi sapi perah di Indonesia tahun 2015 adalah 525.171 ekor dan mengalami peningkatan sebesar $4,51 \%$ bila dibandingkan jumlah populasi sapi perah tahun 2014 yaitu 502.516 ekor. Ironisnya peningkatan jumlah populasi sapi perah itu tidak disertai dengan kenaikan produksi susu, sehingga kebutuhan susu sapi nasional belum dapat terpenuhi.

Bangsa sapi perah yang memiliki produksi susu paling tinggi diantara bangsa sapi adalah sapi Friesian Holstein (FH). Produksi susu sapi perah FH di negara asalnya berkisar 6.000 - 7.000 liter dalam satu masa laktasi (Blakely dan Bade, 1994). Rata-rata produksi susu sapi FH murni yang ada di Indonesia sekitar 10 liter/hari dengan lama laktasi kurang lebih 10 bulan atau produksi susu rata- rata 2.500 - 3.000 liter/laktasi (Prihadi, 1997). Sudono et al. (2003) menambahkan bahwa pada umumnya produktivitas sapi FH di Indonesia masih rendah dengan produksi susu rata-rata 10 liter/ekor/hari atau kurang lebih $3.050 \mathrm{~kg} / \mathrm{laktasi}$.

Kemampuan sapi perah untuk memproduksi susu baik kualitas maupun kuantitas dipengaruhi oleh faktor genetik dan lingkungan. Faktor lingkungan yang berpengaruh yaitu manajemen pemeliharaan, pakan, temperatur, manajemen reproduksi, dan kesehatan. Salah satu usaha untuk meningkatkan produktivitas sapi perah ialah melalui pengendalian penyakit. Salah satu penyakit yang menimbulkan penurunan produksi susu adalah cacingan. Penyakit ternak yang cukup merugikan adalah parasit cacing (Arifin dan Soedarmono, 1982). Penyakit parasit cacing ini dapat menyebabkan kerugian utama, yaitu kurus, terlambatnya pertumbuhan, turunnya daya tahan tubuh terhadap penyakit lain, dan gangguan metabolisme. Parasit juga sering disebut organisme yang hidup atas usaha yang dilakukan organisme lain tanpa memberi imbalan apapun.

Sapi perah rentan terhadap serangan penyakit terutama penyakit fasciolosis (penyakit cacing hati). Menurut Suweta (1984), infestasi cacing hati merupakan salah satu parasit penting pada ruminansia besar di Indonesia. Charlier et al. (2008), melaporkan kerugian ekonomi secara global akibat infestasi cacing hati pada ternak diperkirakan mencapai 36 milyar rupiah per 
tahun. Kerugian ini dapat berupa kematian, penurunan berat badan, kehilangan karkas, kerusakan hati, kehilangan tenaga kerja, penurunan produksi susu $10 \%-20 \%$ dan biaya yang harus dikeluarkan untuk pengobatan.

Penelitian ini dilakukan untuk mengetahui prevalensi cacing hati pada sapi perah di Provinsi Lampung sehingga dapat digunakan sebagai informasi penyusunan program pengendalian dan pencegahan lebih lanjut.

\section{MATERI DAN METODE}

Penelitian ini dilaksanakan pada JuliAgustus 2018 di peternakan sapi perah rakyat Provinsi Lampung dan Laboratorium Parasitologi, Balai Veteriner Lampung.

\section{Materi}

Materi penelitian adalah sampel feses sapi perah segar (baru didefekasikan), $\mathrm{NaCl}$ jenuh, dan Methylene Blue 1\%, kotak pendingin, plastik penampung feses, kuisioner, alat tulis, sarung tangan, timbangan analitik, beaker glass, saringan 100 mesh, tabung kerucut, cawan petri, slide glass, mikroskop, pipet, Mc. Master Plate, dan stopwatch.

\section{Metode}

Metode penelitian adalah metode sensus. Pengambilan data dilakukan dengan cara mengambil sampel feses ternak di peternakan sapi perah rakyat Provinsi Lampung.

Tahapan penelitian yaitu (1) mengetahui jumlah populasi sapi perah pada masing-masing peternakan rakyat di Provinsi Lampung; (2) melakukan wawancara peternak untuk memperoleh data pemeliharaan ternak sapi perah; (3) mengambil sampel feses segar sapi perah; (4) membawa sampel ke Laboratorium Parasitologi Balai Veteriner Lampung dalam kondisi rantai dingin; (5) melakukan metode sedimentasi feses sapi perah; dan (6) menganalisis data secara deskriptif.

Pengambilan feses secara manual dengan cara menggunakan tangan yang dilapisi sarung tangan plastik kemudian sampel diambil dari rektum sapi, setelah feses diambil kemudian dimasukkan ke dalam wadah penampung feses \pm $5 \mathrm{gr} /$ sampel dan diberi label yang berisi keterangan nomor sapi dan kode peternak, asal desa, jenis kelamin, dan umur. Sampel segera disimpan dalam kotak pendingin yang telah berisikan es batu agar kondisi tetap dingin dan mencegah telur menetas. Sampel yang telah diambil kemudian dikirim ke Laboratorium Parasitologi, Balai Veteriner Lampung yang selanjutnya dilakukan pemeriksaan dengan metode sedimentasi.

Metode sedimentasi adalah metode kualitatif untuk mendiagnosa adanya cacing trematode (Fasciola sp.) pada hewan mamalia dengan menemukan telur cacing pada pemeriksaan mikroskopik sampel feses. Prosedur kerja metode sedimentasi di Laboratorium Parasitologi, Balai Veteriner Lampung (BVet Lampung, 2014) sebagai berikut:

1) menimbang 3 gram sampel feses lalu memasukkan ke dalam Beaker glass $100 \mathrm{~mL}$;

2) menambahkan air hingga $50 \mathrm{~mL}$, mengaduk dengan pengaduk hingga feses hancur (homogen);

3) menyaring suspensi dengan saringan 100 mesh dan memasukkan ke dalam tabung kerucut lalu menambahkan air hingga penuh;

4) mendiamkan selama 5 menit, kemudian cairan bagian atas dibuang dan menyisakan filtrat \pm $10 \mathrm{~mL}$;

5) menambahkan air pada filtrat dalam tabung kerucut hingga penuh dan mendiamkan selama 5 menit kemudian membuang lagi cairan bagian atas dan menyisakan $5 \mathrm{~mL}$;

6) menuangkan filtrat ke dalam cawan petri/slide glass khusus dan menambahkan setetes Methylene Blue 1\%, selanjutnya memeriksa di bawah mikroskop dengan pembesaran 100 kali.

Telur Fasciola sp. memiliki morfologi yang hampir sama dengan telur cacing trematode lainnya yaitu Paramphistomum sp. Telur Fasciola $s p$. tidak menyerap warna methylene blue sehingga tetap berwarna kuning emas, terdapat operculum di salah satu kutub telur, dan gambaran sel embryonal tidak begitu jelas.

\section{HASIL DAN PEMBAHASAN}

\section{Kondisi Peternak dan Sapi Perah di Provinsi Lampung \\ Berdasarkan hasil penelitian dari 15} kabupaten/kota di Provinsi Lampung terdapat empat kabupaten/kota yang memiliki ternak sapi perah yaitu Kota Bandar Lampung dengan jumlah sapi perah sebanyak 20 ekor, Kota Metro sebanyak 28 ekor, Kabupaten Lampung Barat sebanyak 39 ekor dan Kabupaten Tanggamus sebanyak 38 ekor, sehingga total sapi perah yang yang digunakan sebagai sampel sebanyak 125 ekor. Daerah tersebut meliputi jumlah sapi perah betina adalah 112 ekor $(10,40 \%)$ dan jantan sebanyak 13 ekor $(89,60 \%)$. Sapi perah di Provinsi Lampung yang masih berumur muda sebanyak 27 ekor $(21,60 \%)$ dan sapi dewasa sebanyak 98 ekor $(78,40 \%)$. Data peternak 
menunjukkan bahwa 3 peternak lulus SD $(17,65 \%), 6$ peternak lulus SMP $(35,29 \%), 7$ peternak lulus SMA $(41,18 \%)$, dan 1 peternak lulus Sarjana $(5,88 \%)$.

Provinsi Lampung memiliki 15 peternak sapi perah dengan sistem pemeliharaan secara intensif atau dikandangkan $(88,24 \%)$, 1 peternak secara semi intensif atau dikandangkan dan digembalakan $(5,88 \%)$, serta 1 peternak secara ekstensif atau digembalakan (5,88\%). Lingkungan kandang yang berdekatan dengan kebun terdapat 10 kandang $(58,82 \%)$ dan 7 kandang berdekatan dengan rumah $(41,18 \%)$. Pakan sapi perah yang diberikan oleh 6 peternak adalah hijauan $(35,29 \%)$ serta 11 peternak memberikan hijauan dan konsentrat $(64,71 \%)$. Sumber air yang digunakan oleh 6 peternak adalah sumur gali $(35,29 \%), 5$ peternak menggunakan sumur bor $(29,41 \%)$, dan 6 peternak menggunakan mata air $(35,29 \%)$. Sanitasi kandang yang dilakukan oleh peternak beragam yaitu 1 peternak melakukan sanitasi 3 kali sehari $(5,88 \%), 13$ peternak membersihkan 2 kali sehari $(76,47 \%), 2$ peternak membersihkan 1 kali sehari $(11,76 \%)$, dan 1 peternak tidak melakukan sanitasi kandang $(5,88 \%)$.

Sebagian besar peternak rakyat sapi perah tidak terlalu memperhatikan riwayat kesehatan ternak, terutama pada ternak yang terkena cacingan. Peternak tidak memberikan obat cacing secara berkala pada sapi perah untuk melakukan penanganan ataupun pencegahan. Pemberian obat cacing yang pernah dilakukan pada ternak sapi perah yaitu sebanyak 57 ekor $(45,60 \%)$ dan terdapat 68 ekor yang tidak pernah diberikan obat cacing $(54,40 \%)$. Persentase prevalensi sapi perah yang terinfestasi cacing Fasciola $s p$. di Provinsi Lampung berjumlah 15 sampel feses (12\%), dengan rincian Kota Metro sebesar 7,14\%, dan Kabupaten Lampung Barat sebesar 33,33\%, sementara Kota Bandar Lampung dan Kabupaten Tanggamus tidak ditemukan. Berikut ini hasil positif Fasciola sp. pada sapi perah di Provinsi Lampung (Tabel 1).

\section{Hasil positif Fasciola sp. sampel feses Sapi Perah di Provinsi Lampung}

Berdasarkan hasil penelitian Provinsi Lampung terbagi menjadi 15 kabupaten/kota. kabupaten/kota yang di wilayahnya ada ternak sapi perahnya adalah Kota Metro, Kota Bandar Lampung, Kabupaten Lampung Barat, dan Kabupaten Tanggamus. Sampel feses sapi perah yang positif terinfestasi Fasciola $s p$. yaitu Kota Metro sebanyak 2 ekor dari 28 ekor sampel feses (7,14\%) dan Kabupaten Lampung Barat sebanyak 13 ekor dari 39 ekor sampel $(33,33 \%)$ sementara Kota Bandar Lampung dan Kabupaten Tanggamus dengan hasil negatif pada semua sampel (Gambar 1).

Tabel 1. Data hasil uji sedimentasi feses sapi perah

\begin{tabular}{llccr}
\hline No. & Kabupaten/Kota & $\begin{array}{c}\text { Jumlah } \\
\text { Sampel } \\
\text { (ekor) }\end{array}$ & $\begin{array}{c}\text { Positif } \\
\text { Fasciola } \mathbf{s p .} \\
\text { (sampel) }\end{array}$ & $\begin{array}{c}\text { Prevalensi } \\
(\boldsymbol{\%})\end{array}$ \\
\hline 1. & Bandar Lampung & 20 & 0 & 0 \\
2. & Metro & 28 & 2 & 7,14 \\
3. & Lampung Barat & 39 & 13 & 33,33 \\
4. & Tanggamus & 38 & 0 & 0 \\
\hline & Provinsi Lampung & $\mathbf{1 2 5}$ & $\mathbf{1 5}$ & $\mathbf{1 2 , 0 0}$ \\
\hline
\end{tabular}

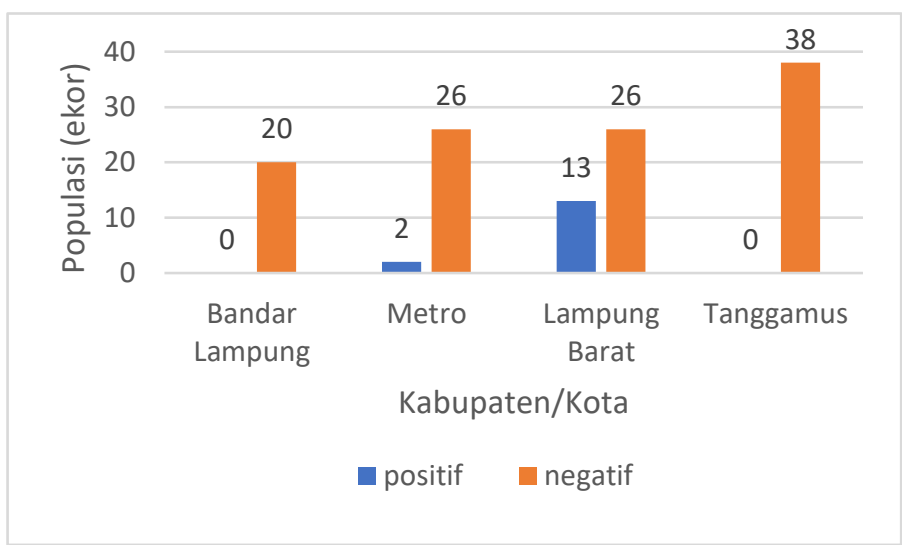

Gambar 1. Hasil positif Fasciola sp. sampel feses sapi perah pada empat kabupaten/kota di Provinsi Lampung 


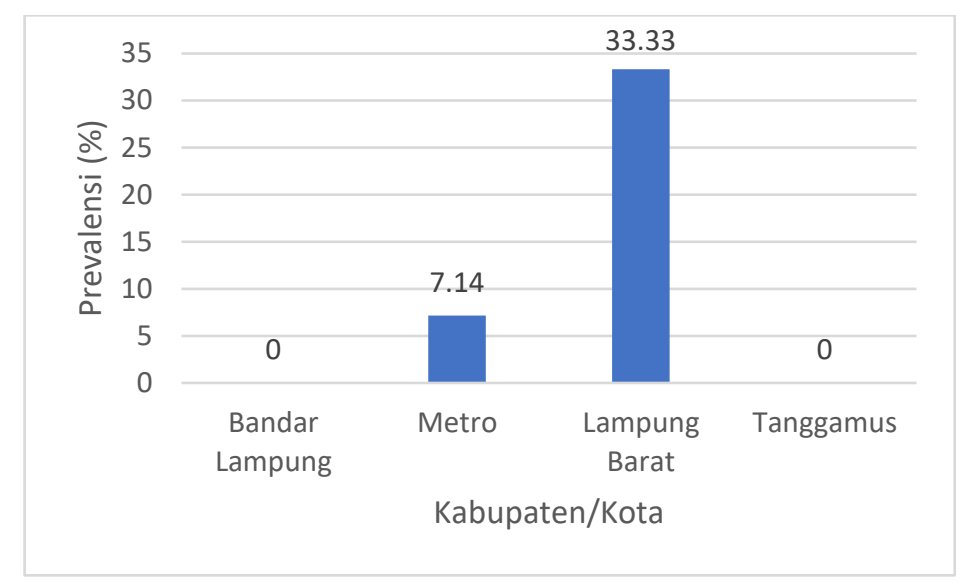

Gambar 2. Prevalensi Fasciola sp. di empat kabupaten/kota di Provinsi Lampung

Gambar 2 menunjukkan bahwa angka prevalensi Fasciola sp. tertinggi terdapat di Kabupaten Lampung Barat sebesar 33,33\%, prevalensi dengan nilai kedua yaitu terdapat di Kota Metro sebesar 7,14\%, dan prevalensi terendah terdapat di Kota Bandar Lampung dan Kabupten Tanggamus sebesar 0\%. Prevalensi cacing hati di Provinsi Lampung sebesar 12,00\%. Angka tersebut didapatkan berdasarkan rumus Budiharta (2002) yaitu :

Prevalensi $=\frac{\text { F }}{\text { N }} \times 100$

Keterangan:

F : Jumlah frekuensi dari setiap sampel yang diperiksa dengan hasil positif

$\mathrm{N}$ : Jumlah dari seluruh sampel yang diperiksa

Tingkat infestasi cacing hati tertinggi di Kabupaten Lampung Barat. Infestasi ini kemungkinan disebabkan oleh air minum yang diberikan terkontaminasi metaserkaria yang siap berkembangbiak dalam hati apabila ikut terminum. Air minum yang diberikan pada sapi perah di sini berasal dari mata air yang ada di rawa yang kemungkinan besar terkontaminasi oleh metaserkaria, keluar dari siput dan berenang di air mencari tanaman yang ada di pinggir perairan

Lokasi lingkungan kandang berupa kebun dengan kondisi lingkungan kandang yang kotor, dan terdapatnya genangan air memungkinkan ternak mudah terinfeksi Fasciola sp. Lingkungan yang kotor dan adanya genangan air dapat menyebabkan tempat siput untuk perkembangbiakan mirasidium. Menurut Noble dan Noble (1989), perkembangan dari stadium telur sampai metaserkaria hanya dapat terjadi pada lingkungan yang tergenang air yang bertindak sebagai faktor pembatas siklus hidup cacing di luar tubuh ternak. Keadaan alam Indonesia dengan curah hujan dan kelembaban yang tinggi memungkinkan parasit seperti cacing berkembang dengan baik dan ditambahkan oleh Mohammed (2008) bahwa sifat hermaprodit Fasciola sp. juga akan mempercepat perkembangbiakan cacing hati tersebut.

Salah satu faktor lainnya yang menyebabkan tingginya tingkat infestasi Fasciola $s p$. yaitu pemberian pakan hijauan dalam keadaan segar. Peternak yang ada di Kabupaten Lampung Barat sebagian besar hanya memberikan pakan berupa hijauan saja. Pemberian pakan berupa hijauan ke ternak dalam keadaan segar dapat memicu terinfestasinya Fasciola sp. pada ternak tersebut, hal ini kemungkinan hijauan tersebut masih tertempel metaserkaria yang siap berkembangbiak dalam hati apabila termakan.

Sapi perah di Kabupaten Lampung Barat jarang dan bahkan ada yang tidak pernah dilakukan tindakan pengobatan sebagai pencegahan. Keadaan tersebut memungkinkan bahwa ternak yang terinfestasi Fasciola sp. karena tidak adanya tindakan pengobatan selama pemeliharaan ternak tersebut berlangsung. Menurut Boray (1969) dan Direktorat Kesehatan Hewan (1980) pengobatan sebaiknya dilakukan sebanyak 3 kali dalam setahun, yaitu pada permulaan musim hujan untuk membasmi cacing yang diperoleh ternak selama musim kemarau, pada pertengahan musim hujan untuk membasmi cacing yang diperoleh selama musim hujan, dan mengurangi infestasi siput oleh mirasidium, serta pada akhir musim hujan untuk membasmi cacing yang diperoleh selama musim hujan dan mengurangi pencemaran lapangan oleh telur cacing hati di musim kemarau.

Prevalensi cacing Fasciola sp Kota Metro berada pada urutan kedua yaitu 7,14\%. Tingginya 
prevalensi cacing Fasciola sp di Kota Metro diduga karena ternak sapi perahnya jarang diobati yaitu pemberian terakhir obat cacing adalah satu tahun yang lalu. Menurut BPPTP Kalbar (2006), pengobatan sangat penting dilakukan sebagai upaya pencegahan ternak terinfestasi penyakit cacingan terutama cacing hati. Pencegahan penyakit dapat dilakukan dengan obat cacing yang diberikan setiap 2 bulan sekali.

Prevalensi Fasciola sp. terendah di Kota Bandar Lampung dan Kabupaten Tanggamus yaitu tidak ada infestasi yang terdapat pada sapi perah di wilayah tersebut. Rendahnya prevalensi ini diduga dapat disebabkan oleh tidak adanya siput di lokasi kandang sehingga mirasidium tidak memiliki inang antara untuk melanjutkan daur hidupnya menjadi metaserkaria. Menurut Brown (1979), tubuh mirasidium diliputi silia yang berfungsi sebagai alat penggerak di air. Noble dan Noble (1989), melaporkan bahwa mirasidium hanya hidup dalam waktu singkat (24 jam) untuk mencari siput sebagai induk semang antara. Mirasidium akan melekat jika ditemukan siput yang sesuai dan menusukkan papillanya. Silia dilepaskan setelah mirasidium berhasil menembus jaringan siput kemudian menempati rumah siput tersebut. Mirasidium berbentuk gelembung dengan setelah 36 jam, dinding transparan yang disebut sporokista. Setiap mirasidium berkembang menjadi sebuah sporokista di dalam tubuh siput.

Persentase prevalensi cacing Fasciola $s p$ di Provinsi Lampung yaitu sebesar 12\%. Angka tersebut lebih rendah dari penelitian Zalizar (2017) pada sapi perah di peternakan yang tergabung di Koperasi KUBE di Jabung Kabupaten Malang yaitu rata rata 23,58\% dan penelitian Jusmaldi dan Saputra (2009), pada ternak sapi potong yang disembelih di RPH Samarinda yang mencapai $44,44 \%$.

Prevalensi fasciolasis di setiap wilayah berbeda-beda, hal ini berkaitan dengan perbedaan geografis (faktor ekstrinsik) yang mempengaruhi keberadaan siput sebagai hospes antara dan daya tahan metaserkaria di lingkungan (Mage et al., 2000; Melaku dan Addis, 2012). Tasawar et al. (2007) menambahkan perbedaan bangsa atau jenis ternak jg dapat mempengaruhi prevalensi Fasciola sp.

Faktor intrinsik yang mempengaruhi adanya infestasi Fasciola sp. yaitu umur dan pemberian obat cacing. Berdasarkan penelitian ini Sapi perah yang terinfestasi Fasciola sp. rata-rata berumur $\geq 4$ tahun. Menurut Hambal et al. (2013), infestasi Fasciola sp. pada sapi di pengaruhi oleh umur, semakin tua umur sapi maka semakin tinggi pula resiko infestasinya terhadap Fasciola sp. Sayuti (2007), menambahkan bahwa
Sapi Bali berumur lebih dari 12 bulan lebih rentan terhadap infestasi Fasciola sp. dibandingkan dengan Sapi Bali berumur kurang dari 6 bulan dan antara 6-12 bulan. Metaserkaria berdinding tebal berlapis dua apabila termakan oleh sapi dewasa di dalam lambungnya dinding kista yang berhasil dihancurkan oleh asam lambung hanya lapisan luar saja. Sapi perah muda prevalensi fasciolasis lebih rendah, hal ini disebabkan oleh sapi muda masih konsumsi air susu dari induknya dan konsumsi rumput sapi muda pun masih rendah dibandingkan dengan sapi dewasa sehingga memungkinkan untuk terinfestasi larva metaserkaria lebih rendah.

\section{SIMPULAN}

Berdasarkan hasil penelitian dapat diambil simpulan bahwa prevalensi cacing hati pada sapi perah di Provinsi Lampung adalah sebesar $12,00 \%$. Prevalensi cacing hati tertinggi terdapat pada sapi perah di Kabupaten Lampung Barat sebesar 33,33\%, sedangkan prevalensi cacing hati terendah terdapat pada sapi perah di Kota Bandar Lampung dan Kabupaten Tanggamus sebesar 0\%.

\section{DAFTAR PUSTAKA}

Arifin, C. dan Soedarmono. 1982. Parasit Ternak dan Cara Penanggulangannya Kanisius. Yogyakarta

Balai Pengkajian dan Pengembangan Teknologi Pertanian. 2006. Teknologi Penggemukan Sapi.

http://www.bisnisbali.com/New/opini/t.ht $\underline{\mathrm{ml}}$. Diakses pada 2 Desember 2017

Balai Veteriner Lampung. 2014. Penuntun Teknis Pengujian Laboratorium Parasitologi. Balai Veteriner Lampung. Bandar Lampung

Blakely, J. and D. H. Bade. 1994. The Science of Animal Husbandry. Diterjemahkan oleh Srigandono, B. Ilmu Peternakan. Edisi ke 4. Gadjah Mada University Press. Yogyakarta

Boray, J. C. 1969. Experimental fascioliasis in Australia. Advances Parasitology London 7:95-210.

Brown, H. W. 1979. Dasar Parasitologi Klinis. Edisi 3, Terjemahan oleh

B. Rukmono, Hoedojo, N.S. Djakaria, S.D. Soeprihatin, S.S. Margono, S. Oemijati, S. Gandahusada dan W. Pribadi. PT Gramedia. Jakarta

Budiharta, S. 2002. Kapita Selekta Epidemiologi Veteriner. Bagian Kesehatan Masyarakat Veteriner. Fakultas Kedokteran Hewan. Universitas Gadjah Mada. Yogyakarta 
Charlier J., D. L. Meulemeester, E. Claerebout, D. Williams, and J. Vercruysse. 2008. Qualitative and quantitative evaluation of coprological and serological techniques for the diagnosis of fascioliasis in cattle. Vet. Parasitology 153: 44-51

Direktorat Kesehatan Hewan. 1980. Pedoman Pengendalian Penyakit Hewan Menular Jilid II. Direktorat Kesehatan Hewan Dirjen Peternakan Departemen Pertanian. Jakarta

Hambal, M., S. Arman., dan D. Agus. 2013. Tingkat kerentanan Fasciola gigantica pada Sapi dan Kerbau di Kecamatan Lhoong, Kabupaten Aceh Besar. J. Med. Vet. 7(1): 49-52

Jusmaldi dan Saputra, Y. 2009. Prevalensi Infeksi Cacing Hati (Fasciola hepatica) pada Sapi Potong di Rumah Potong Hewan Samarinda. Jurusan Biologi FMIPA Universitas Mulawarman. Bioprospek. 6 (2): 55-61

Kementerian Pertanian Republik Indonesia. 2015. Populasi Sapi Perah di Indonesia. http://www.pertanian.go.id/ASEM2015NAK/Pop_SapiPerah_Prop_2015.pdf. Diakses pada 17 April 2016

Mage, C., C. Bourgne, J. M. Toullieu, D. Rondelaud, and G. Dreyfuss. 2002. Fasciola hepatica and Paramphistomum daubneyi: changes in prevalences of natural infections in cattle and in Lymnaea truncatula from central Franceover the past 12 years. Vet. Research 33(5): 439-447

Melaku, S., dan M. Addis. 2012. Prevalence and intensity of Paramphistomum in ruminants slaughtered at Debre Zeit Industrial Abattoir, Ethiopia. Global Vet. 8(3): 315319

Mohammed, N. 2008. Fasciola hepatica. http://www.nenadmohamed.com.htm. Diakses pada 8 Desember 2017

Noble, E.R. dan G.A. Noble. 1989. Parasitologi, Biologi, Parasit Hewan Edisi Kelima, Terjemahan oleh Wardiarto. Gadjah Mada University Press. Yogyakarta

Prihadi, S. 1997. Dasar Ilmu Ternak Perah. Fakultas Peternakan Universitas Gadjah Mada. Yogyakarta

Sayuti, L. 2007. Kejadian Infeksi Cacing Hati (Fasciola sp.) Pada Sapi Bali Di Kabupaten Karangasem, Bali. Skripsi. Fakultas Kedokteran Hewan. Institut Pertanian Bogor. Bogor

Sudono, A., F. Rosdiana, dan B. S. Setiawan. 2003. Beternak Sapi Perah Secara Intensif. Agromedia Pustaka. Jakarta

Suweta, I. G. P.1984. Penyuluhan Penanggulangan Penyakit Parasiter pada Ternak di Kabupaten Gianyar. Laporan Pengabdian. Pusat Pengabdian pada Masyarakat. Universitas Udayana. Denpasar

Tasawar Z., U. Minir, C.S. Hayat and M.H. Lashari. 2007. The Prevalence of Fasciola hepatica in Goats Around Multan. Pakistan Vet. J.27(1): 5-7

Zalizar L. 2017. Helminthiasis saluran cerna pada sapi perah. J. I. Pet. 27 (2): $116-122$ 